\title{
Kırım Kongo Kanamalı Ateşini Taklit Eden İki Pediatrik Bruselloz Olgusu
}

\section{Two Pediatric Cases of Brucellosis Mimicking Crimean-Congo Hemorrhagic Fever}

Ömer GÜNEȘ , Saliha KANIK YÜKSEK, Latife GÜDER, Özlem MUSTAFAOĞLU , Ahmet Yasin GÜNEY, Belgin GÜLHAN, Gülsüm İclal BAYHAN, Aslınur ÖZKAYA PARLAKAY

Ankara Şehir Hastanesi, Çocuk Enfeksiyon Hastalıkları Kliniği, Ankara, Türkiye

\begin{abstract}
öz
Bruselloz pastörize edilmemiş süt ve süt ürünlerinin ağız yoluyla alınmasıyla veya enfekte hayvan salgılarılyla yakın temas yoluyla bulaşan, gram negatif bir kokobasil olan Brucella türlerinin neden olduğu ülkemizde de yaygın olarak görülen zoonotik bir hastalıktır. Bruselloz özgül olmayan semptom ve bulgulara sahip olması nedeniyle diğer birçok hastalığı taklit edebilir. Kırım Kongo Kanamalı Ateși (KKKA) brusellozun ayıııı tanısında yer alan zoonotik bir hastalıktır. Bu yazıda KKKA ön tanısı ile hastanemize sevk edilen ve bruselloz tanısı konulan iki pediatrik olgu sunulmuş̧ur.
\end{abstract}

Anahtar Sözcükler: Bruselloz, Çocuk, Kırım Kongo Kanamalı Ateși

\begin{abstract}
Brucellosis is a common zoonotic disease in our country caused by Brucella species, a gram negative coccobacillus that is transmitted by oral ingestion of unpasteurized milk and dairy products or by close contact with infected animal secretions. Because brucellosis has nonspecific symptoms and findings, it can mimic many other diseases. CrimeanCongo Hemorrhagic Fever (CCHF) is a zoonotic disease included in the differential diagnosis of brucellosis. In this article, two pediatric cases referred with a pre-diagnosis of CCHF and diagnosed with brucellosis were presented.
\end{abstract}

Key Words: Brucellosis, Child, Crimean Congo Hemorrhagic Fever

\section{GiRiş}

Bruselloz yüksek ateş, eklem ağrısı, halsizlik, iştahsızlık, karın ağrısı ve baș ağrısı gibi özgül olmayan semptomlar ile hepatosplenomegali ve lenfadenopati gibi bulgulara sahip olan zoonotik bir enfeksiyon hastalığıdır (1). Bu semptom ve bulgular nedeniyle bruselloz, sıklıkla hemato-onkolojik, romatolojik hastalıklar ve enfeksiyon hastalıkları ile karışabilmektedir (2). Enfeksiyöz nedenlerden olan KKKA insanlara enfekte kenelerin tutunmasıyla ve enfekte hayvanların kan ve dokuları ile temas sonucunda bulaşan zoonotik bir hastalıktır. Özgül olmayan semptomlarla bir haftadan daha kısa süren inkübasyon süresi sonrası görülür (3). Kanama, trombositopeni, pansitopeni ve dissemine intravasküler koagülopati gibi önemli hematolojik bulgulara ve mortaliteye neden olabilen bir hastalıktır (4). Bu olgu sunumunda benzer klinik ve laboratuvar özelliklerine sahip olup illk değerlendirmede KKKA ön tanısı konulup merkezimize refere edilen ve ayırıcı tanı sonrasında bruselloz tanısı konulan iki pediatrik olgu tartışılmıştır.

\section{OLGU 1}

Öncesinde sağlıklı 14 yaşında kız hastanın üç gündür devam eden ateş, ishal ve karın ağrısı yakınmalarıyla hastanaye başvurduğu öğrenildi. Köyde yaşayan ve ailesi hayvancılıkla
GÜNEŞ Ö

KANIK YÜKSEKS

GÜDER L

MUSTAFAOĞLU Ö

GÜNEY AY

GÜLHAN B

BAYHAN B

ÖZKAYA PARLAKAY S
0000-0001-7121-3810 0000-0002-2538-2872 0000-0003-4565-3665

0000-0001-8915-6922

0000-0002-3446-7034

0000-0003-0839-1301

:0000-0002-1423-4348

0000-0001-5691-2461
Çıkar Çatışması / Conflict of Interest: : Tüm yazarlar adına, ilgili yazar çıkar çatışması olmadığını belirtir.

Finansal Destek / Financial Disclosure: Yazarlar bu olgu için finansal destek almadıklarını beyan etmişlerdir.

Onay / Confirmation: Kayıt sırasında veliler tarafından araştırmaya katılım için bilgilendirilmiş bir onay imzalanmıştır.

Atıf yazım şekli / How to cite : Güneș Ö, Kanık Yüksek S, Güder L, Mustafaoğlu Ö, Güney AY, Gülhan B ve ark. Kırım Kongo Kanamalı Ateșini Taklit Eden Iki Pediatrik Bruselloz Olgusu. Türkiye Çocuk Hast Derg 2021;15:538-541.
Yazıșma Adresi / Correspondence Address:

Ömer GÜNEŞ

Ankara Șehir Hastanesi, Çocuk Enfeksiyon Hastalıkları Kliniği, Ankara, Türkiye

E-posta: dromergunes@gmail.com
Geliş tarihi / Received : : 12.11.2020 Kabul tarihi / Accepted : 02.03.2021 Elektronik yayın tarihi : 23.09 .2021 Online published

DOI: 10.12956/tchd.823943 
uğraşan hasta, pansitopeni saptanması üzerine yaşadığı bölgede endemik olması ve hastalı̆ın görüldüğü mevsimsel dönem içerisinde olunması nedeniyle KKKA düşünülerek hastanemize sevk edildi. Kene tutunma öyküsü olmayan hastanın pastörize edilmemiş süt ve süt ürünleri tüketme hikayesi mevcuttu. Hastanın hastanemize başvurusu esnasında $38^{\circ} \mathrm{C}$ olan vücut sıcaklığı dışında diğer vital bulguları normaldi. Fizik muayenede, karaciğer ve dalak kosta altında midklaviküler hatta $1 \mathrm{~cm}$ kadar ele gelmekteydi.

Tam kan sayımında beyaz küre sayısı 1700 (4500-11400) / $\mathrm{mm}^{3}$, hemoglobin 9.4 (12.5-16) g/dL, trombosit sayısı 79.000 (170000-400000) / $/ \mathrm{mm}^{3}$ saptandl. C-reaktif protein (CRP) 25.8 (0-5) mg/L, protrombin zamanı (PTZ) 11.3 (9.8 -14) sn, international normalized ratio (INR) 1.24 (0.8-1.2) ve aktive parsiyel tromboplastin zamanı (aPTT) 31.9 (21 -32) sn'di. Kan biyokimyasında alanin aminotransferaz (ALT) 24 (0-29) U/L, aspartat aminotransferaz (AST) 54 (0-25) U/L, laktat dehidrojenaz (LDH) 614 (0-287) U/L ve kreatin kinaz (CK) 147 (<247) U/L tespit edildi. Abdominal ultrasonografide hepatosplenomegali mevcuttu. Periferik yaymada atipik hücreye rastlanmadı. Semptom ve laboratuvar bulgularının hastalıkla uyumlu olması ve hastanın endemik bölgede yaşıyor olması nedeniyle KKKA için istenen ELISA (Enzyme-Linked ImmunoSorbent Assay) ve PZR (Polimeraz zincir reaksiyonu) testleri negatif olarak sonuçlandı. Kene tutunma öyküsü de olmayan hastada KKKA tanısından uzaklaşıldı. Diğer olası enfeksiyöz nedenler düşünülerek ayırııı tanıya yönelik olarak gönderilen sitomegalovirüs, Ebstein-Barr virüs ve parvovirüs serolojik testleri negatif olarak tespit edildi. Bruselloz açısından yapilan tetkiklerinde ise Rose Bengal testi pozitif, Brucella IgM 10.0 (>1.1 pozitif) RU/mL, Brucella IgG 37.38 (>22 pozitif) RU/ $\mathrm{mL}$ ve Brucella tüp aglütinasyonu 1:5120 titrede pozitif olarak saptandı. Yatışının altıncı gününde kan kültüründe gram negatif kokobasil sinyali olduğu ve sonrasında Brusella spp üremesi olduğu öğrenildi. Hastaya sonuçlarla bruselloz tanısı konularak doksisiklin (4.4 mg/kg/gün) ve rifampisin (20 mg/kg/gün) tedavileri başlandı. Tedavi başlanmasından kısa süre sonra sistemik semptomları geriledi ve pansitopeni bulgusu düzeldi. Tedavi altında alınan kontrol kan kültüründe üreme olmadı. Ek sistem tutulumu olmayan hasta almakta olduğu antibiyotik tedavileri 6 haftaya tamamlanacak şekilde ayaktan yakın takip edilmek üzere taburcu edildi.

\section{OLGU 2}

Öncesinde sağliklı 14 yaşında erkek hastanın iki gündür devam eden ateş, bir haftadır devam eden kas ağrısı, eklem ağrısı ve halsizlik yakınmaları ile dış merkezdeki bir hastaneye başvurduğu ve KKKA ön tanısı ile merkezimize sevk edildiği öğrenildi. Köyde yaşayan ve ailesi hayvanclıkla uğraşan hastanın pastörize edilmemiş süt ve süt ürünü tüketme öyküsü mevcut iken yakın zamanda kene tutunması yoktu. Hastanemize başvurusu sırasında vücut sıcaklığı $38^{\circ} \mathrm{C}$ ölçüldü. Diğer vital bulgular ve fizik muayenesi normaldi.

Tam kan sayımında beyaz küre sayısı $1800 / \mathrm{mm}^{3}$, hemoglobin $12.5 \mathrm{~g} / \mathrm{dL}$ trombosit sayısI $96.000 / \mathrm{mm}^{3}$ 'di. CRP $17 \mathrm{mg} / \mathrm{L}$, PTZ 12.8 sn, INR 1.23 ve aPTT 29.4 sn olarak sonuçlandı. Biyokimyasal incelemelerinde ALT $54 \mathrm{U} / \mathrm{L}$, AST $58 \mathrm{U} / \mathrm{L}$, LDH $523 \mathrm{U} / \mathrm{L}$ ve CK 170 U/L'di. Periferik yayma incelemesinde malign hücre saptanmadı. Hastanın klinik ve laboratuvar bulgularının KKKA enfeksiyonunu düşündürmesi ve endemik bölgeden başvurmuş olması nedeniyle hastalığa yönelik gönderilen ELISA ve PZR testleri negatif olarak görüldü. KKKA tanısından uzaklaşılan hastada ayıııcı tanıya yönelik olarak gönderilen viral serolojik testler negatif olarak sonuçlanırken, Brucella Rose Bengal pozitif, Brucella IgM 10.0, Brucella IgG 37.38 RU/mL ve Brucella tüp aglütinasyonu 1:640 titrede pozitif olarak tespit edildi. Ateşleri ampirik olarak başlanan seftriakson (100 mg/kg/gün) alıında devam eden hastanın yatışının beşinci gününde kan kültüründe gram negatif kokobasil sinyali olduğu öğrenildi. Bruselloz tanısı ile hastaya doksisiklin (4.4 $\mathrm{mg} / \mathrm{kg} / \mathrm{gün}$ ) ve rifampisin (20 mg/kg/gün) tedavisi başlandı. Tedavi başlanmasından kısa süre sonra ateşi düştü, anormal laboratuvar bulguları düzeldi. Kan kültüründe üreyen gram negatif kokobasil Brucella spp olarak raporlandı. Bruselloz tedavisi altında alınan kontrol kan kültüründe üreme görülmedi. Yapılan sistemik incelemede ek sistem tutulumu saptanmayan hasta başlanmış olan antibiyoterapisi ayaktan 6 haftaya tamamlanmak üzere taburcu edildi.

\section{TARTIŞMA}

Bruselloz insanlara pastörize edilmemiş hayvan ürünlerinin ağız yoluyla alınmasıyla, enfekte hayvan salgılarılla doğrudan temas veya kontamine aerosollerin inhalasyonu sonucu enfeksiyöz aerosollerin solunmasıyla bulaşan zoonotik bir hastalıktır (5). Hastalık etkeni gram negatif bir kokobasil olan Brucella türleridir. Ülkemizde endemik olan bruselloz, özellikle hayvancllğın yaygın olarak yapıldığı Doğu Anadolu ve Güneydoğu Anadolu bölgelerinde sıklikla görülmektedir (6).

Brusellozda en sık görülen semptomlar ateş, eklem ağrısı ve karın ağrısı gibi özgül olmayan semptomlardır. Ülkemizde bruselloz tanısı alan çocuklar ile yapılan retrospektif bir çalışmada da en

sık görülen klinik semptomlar ateş, eklem ağrısı, halsizlik, baş ağrısı, gece terlemesi ve kilo kaybı olarak saptanmıştır $(5,6)$. Brusellozda en sık görülen klinik bulgular ise sırasıyla ateş, periferik artrit ve hepatosplenomegalidir (6). Olgularımızın her ikisi de ateş, eklem ağrısı, karın ağrısı ve halsizlik gibi bruselloz 
için özgül olmayan semptomlarla başvurmuşlardı. Ancak sadece birisinde fizik muayenede hepatosplenomegali saptanmıştı.

Bruselloz hastalarında alınan rutin laboratuvar tetkikleri nonspesifiktir ve tanı koydurmaz. Anormal hematolojik bulgulara sıklıkla rastlanmaktadır $(6,7)$. Tek bașına anemi, Iökopeni ve trombositopeni saptanabildiği gibi bisitopeni veya pansitopeni de görülebilmektedir (7). Ülkemizde pediatrik hastalar ile yapılan bir çalsşmada akut bruselloz tanısı konan hastaların hematolojik bulguları değerlendirilmiş, olguların \%16'sında trombositopeni, \%13.9'unda lökopeni, \%7.7'sinde pansitopeni ve \%4'ünde bisitopeni bulunmuştur (8). Pediatrik bruselloz olgularında pansitopeni gelişse bile tedavi ile düzelmektedir (9). Olgularımızın ikisinde de başvuruları sırasında pansitopeni tablosu mevcut olup tedavi ile hızlı bir şekilde düzeldikleri görülmüştür. Bruselloz hastalarında baklan diğer testlerden CRP ve sedimentasyon gibi akut faz reaktanları ile karaciğer fonksiyon testleri gibi biyokimyasal parametreler de anormallikler saptanabilmektedir (6). Ancak tanı koydurucu değillerdir ve sadece organ tutulumları ile tedavi yanıımın değerlendirilmesinde yardımcı olurlar $(6,7)$.

Bruselloz özgül olmayan semptomlar ve bulgulara sahip olması nedeniyle sinsi bir seyir gösterebilmekte ve diğer birçok hastalığı taklit edebilmektedir (10). Akut, subakut ve kronik formları görülebilmekle birlikte çocuklarda en çok akut formu görülmektedir (11). Türkiye'nin Orta Anadolu ve Doğu Anadolu bölgelerinde endemik olarak görülen ve zoonotik bir hastalık olan KKKA ile büyük benzerlikler gösterir. Bruselloz insidansı özellikle hayvanların yavrulama dönemleri ve peynir yapımının artıı̆ı ilkbahar ve yaz aylarında artmaktadır. KKKA hastalığı da mevsimsel değişkenlik göstermekte ve bruselloza benzer şekilde havaların ısındığı likbahar sonu ve yaz aylarında endemik bölgelerde ortaya çıkmaktadır. Başlangıçta KKKA olarak değerlendirilen daha sonra yapılan incelemelerde bruselloz tanısı konulan pediatrik olgular bildirilmiştir (10). Endemik bölgede yaşayan erişkin bir hastada KKKA ve bruselloz koenfeksiyonuna ait olgu bildirimi de bulunmaktadır (11). KKKA tanısı konmuş hastaların sadece \%69 ' unda kene tutunması öyküsü bildirildiğinden, kene teması olmasa bile enfeksiyonun

görüldüğü dönemde endemik bölgede bulunan ve hastalığı düşündüren klinik ve/veya laboratuvar bulgusu ile başvuran hastalarda KKKA tanısı akla gelmeli ve tanıya yönelik tetkikler gönderilmelidir (12).

Burada sunulan her iki olguda da KKKA tanısı akla gelmiş ve hastalar merkezimize sevk edilmişlerdi. KKKA'a yönelik PZR ve ELISA testlerinin negatif sonuçlanması ve hastalarda pastörize edilmemiş süt/süt ürünü tüketimi ve ailelerinin hayvanclıkla uğraşıyor olmaları nedeniyle ülkemizde endemik olarak görülen brusellozdan șüphelenildi ve tanıya yönelik tetkikler planlandı.

Bruselloz tanısında altın standart yöntem etkenin kültürde üretilmesidir (6). Ancak kültürlerde üreme oranlarının düşük olması nedeniyle serolojik testler tanıda oldukça önemli yer tutmaktadır (7). Lam (Rose Bengal) ve tüp aglutinasyon testleri günlük pratikte sıklıkla kullanılmaktadır (6).

Sunduğumuz her iki olgunun da kan kültürlerinde Brucella spp ürerken, Brusellaya yönelik seroloji ve aglutinasyon testleri de pozitif olarak sonuçlandı.

Bruselloz tedavisinde amaç hastalığı kontrol altına almak ve komplikasyon, nüks ile sekel gelişimini önlemektir. Brucella türlerininhücreiçimikroorganizmalarolmasınedeniyleintrasellüler ortamda etkinlik gösteren doksisiklin, rifampisin ve trimetoprim/ sulfametoksazol gibi antibiyotikler kullanilir ve monoterapide nüks oranlarının yüksek olması nedeniyle kombinasyon tedavisi şeklinde uzun süreli uygulanılar. Brusellozun standart tedavisi 6 hafta olup, spondilit, nörobruselloz ve endokardit gibi fokal hastalık bulgusu varlığında 4-6 aya kadar uzatılabilmektedir (13). İki olgumuzda da uzun süreli tedavi gerektiren endikasyonlar bulunmadığından 6 haftalık kombine doksisiklin ve rifampisin tedavisi uygulanmıştır (14).

Sonuç olarak, bruselloz ve KKKA ülkemizde endemik olarak görülen ve benzer klinik özelliklere sahip zoonotik hastalıklardır. KKKA hastalığının tespit edilmediği özgül olmayan semptom ve bulgularla başvuran hastalarda gecikmiş tanı ve tedavi neticesinde kayıplara yol açabileceğinden bruselloz akılda tutulmalı ve tanıya yönelik uygun tanı testleri yapılmalıdır.

\section{KAYNAKLAR}

1. Seleem MN, Boyle SM, Sriranganathan N. Brucellosis: a reemerging zoonosis. Vet Microbiol 2010;140:392-

2. Yagupsky P. Pediatric brucellosis: an (almostforgotten disease. Adv Exp Med Biol 2011;719:123-

3. Tuygun N, Tanir G, Caglayik DY, Uyar Y, Korukluoglu G, Cenesiz F. Pediatric cases of Crimean-Congo hemorrhagic fever in Turkey. Pediatr Int 2012;54:402-6.

4. Onguru P, Dagdas S, Bodur H, Yilmaz M, Akinci E, Eren S, Ozet G. Coagulopathy parameters in patients with Crimean-Congo hemorrhagic fever and its relation with mortality. J Clin Lab Anal 2010;24:163-6.

5. Young EJ, Brucellosis RD, Feigin JD, Cherry GJ, Demmler SL. Kaplan (eds). Textbook of pediatric infectious diseases. 5th ed. Philadelphia: Saunders Co 2004:1582-7.

6. Kanık Yüksek S, Gülhan B. Çocukluk Çağında Bruselloz: Tek Merkez Deneyimi. Türkiye Çocuk Hast Derg 2019;6:435-41.

7. Kara SS, Kara D, Fettah A. Various clinical conditions can mimic Crimean-Congo hemorrhagic fever in pediatric patients in endemic regions. J Infect Public Health 2016;9:626-32.

8. Karaman K, Akbayram S, Bayhan GI, Doğan M, Parlak M, Akbayram $H T$, et al. Hematologic Findings in Children With Brucellosis: Experiences of 622 Patients in Eastern Turkey. J Pediatr Hematol Oncol 2016;38:463-6.

9. Karli A, Şensoy G, Albayrak C, Koken O, Cıraklı S, Belet N, et al. Pancytopenia As the Initial Manifestation of Brucellosis in Children. Vector Borne Zoonotic Dis 2015;15:545-9. 
10. Metin O, Teke TA, Aydin ZGG, Kaman A, Oz FN, Bayhan GI, et al. A case of brucellosis mimicking Crimean-Congo hemorrhagic fever. Journal of Infection and Public Health 2015;8:302-4.

11. Yoldas T, Tezer H, Ozkaya-Parlakay A, Sayli TR. Clinical and laboratory findings of 97 pediatric brucellosis patients in central Turkey. J Microbiol Immunol Infect 2015;48:446-9.

12. .Karakeçili F, Çıkman A, Akın H, Gülhan B, Özçiçek A. A case of brucellosis and Crimean-Congo hemorrhagic fever coinfection in an endemic area. Mikrobiyol Bul 2016;50:322-7.
13. Yilmaz GR, Buzgan T, Irmak H, Safran A, Uzun R, Cevik MA, Torunoglu MA. The epidemiology of Crimean-Congo hemorrhagic fever in Turkey, 2002-2007. Int J Infect Dis 2009;13:380-6.

14. Young EJ. Brucella Species (Brucellosis). In: Sarah S. Long, Charles G. Prober, Marc Fischer (eds). Principles and Practice of Pediatric Infectious Diseases. Fifth edition. Elsevier 2017:4563-4.

15. Tanir G, Tufekci SB, Tuygun N. Presentation, complications, and treatment outcome of brucellosis in Turkish children. Pediatr Int 2009;51:114-9. 